\title{
Gap junction modulation and its implications for heart function
}

\author{
Stefan Kurtenbach ${ }^{1}{ }^{*}$, Sarah Kurtenbach ${ }^{1}$ and Georg ZoidI I,2,3 \\ ${ }^{1}$ Department of Psychology, Faculty of Health, York University, Toronto, ON, Canada \\ 2 Department of Biology, Faculty of Science, York University, Toronto, ON, Canada \\ ${ }^{3}$ Center for Vision Research, York University, Toronto, ON, Canada
}

Edited by:

David C. Spray, Albert Einstein

College of Medicine, USA

Reviewed by:

Michael Tamkun, Colorado State

University, USA

Francisco F. De-Miguel, Universidad

Nacional Autonoma de Mexico,

Mexico

${ }^{*}$ Correspondence:

Stefan Kurtenbach, Molecular and

Cellular Neuroscience, Department

of Psychology, Faculty of Health,

York University, LSB 323A, 4700

Keele Street Toronto, ON M3J 1P3,

Canada

e-mail: stefan.kurtenbach@me.com
Gap junction communication (GJC) mediated by connexins is critical for heart function. To gain insight into the causal relationship of molecular mechanisms of disease pathology, it is important to understand which mechanisms contribute to impairment of gap junctional communication. Here, we present an update on the known modulators of connexins, including various interaction partners, kinases, and signaling cascades. This gap junction network (GJN) can serve as a blueprint for data mining approaches exploring the growing number of publicly available data sets from experimental and clinical studies.

Keywords: gap junction communication, connexin, heart, interactome, signaling pathway

\section{GAP JUNCTION COMMUNICATION IN HEALTH AND DISEASE}

Gap junction communication (GJC) describes the electrical and metabolic coupling of cells through specialized cell contacts called gap junctions. In vertebrates, gap junctions are present in most tissues having important roles in development, growth regulation, tissue homeostasis, and communication. They assemble from homo- or hetero-hexameric connexin hemichannels encoded by 20 (rodents) or 21 (human) different genes (Söhl et al., 2005). GJC has been studied in great detail for the last 50 years. These studies emphasized important molecular, biophysical properties, and physiological roles of connexin channels. Other studies revealed connexin structures down to atomic resolution (Maeda et al., 2009; Grosely and Sorgen, 2013) and a multitude of regulatory mechanisms controlling the entire life cycle of these channels from transcription, post-translational modification, to removal of gap junctions and degradation (Laird, 2006; Johnstone et al., 2012a; Su et al., 2012; Thévenin et al., 2013). More recent work demonstrated connexin hemichannel functions under physiological conditions (Bruzzone et al., 2001; Anselmi et al., 2008; Garré et al., 2010) and evidence for channel independent function, e.g., in cell growth and death (Vinken et al., 2012) or migration (Kameritsch et al., 2012). Mutations in connexins were discovered in inherited human diseases like oculodentodigital dysplasia (ODDD, Cx43, GJA1; Huang et al., 2013), X-linked Charcot-Marie-Tooth disease (Cx32, GJB1; Scherer and Kleopa, 2012), Pelizaeus-Merzbacher-like disease or a milder spastic paraplegia (Cx47; Kleopa et al., 2010), Vohwinkel syndrome as well as Keratitis-Icthyosis-Deafness (KID) syndrome (Cx26, GJB2; Lee and White, 2009; Xu and Nicholson, 2013), Erythrokeratodermia variabilis (Cx31, GJB3; Cx30.3, GJB4), Clouston syndrome
(Cx30, GJB6) or secondary lymphedema following breast cancer treatment (Cx47, GJC2; Finegold et al., 2012). Furthermore, transcriptional and post-transcriptional alterations and dysfunctional degradation by autophagy (Lichtenstein et al., 2011; Fong et al., 2012) may represent indirect mechanisms causing impaired GJC. Today, a causal relationship, e.g., in the context of seizures ( $\mathrm{Li}$ et al., 2001; Gajda et al., 2005; Samoilova et al., 2008), cerebral ischemia (Contreras et al., 2004; Talhouk et al., 2008; Orellana et al., 2010), autism (Fatemi et al., 2008), schizophrenia (Meyer et al., 2002; Aleksic et al., 2007), and after trauma (Frantseva et al., 2002) seems plausible. Thus, understanding the exact roles of GJC in health and disease is a highly relevant and timely objective in biomedical and preclinical research. Transcriptome studies have started to provide valuable insight into the consequences of altered connexin expression in animal models (Spray and Iacobas, 2007; Iacobas et al., 2012, 2007a), exploring the use of coordination analysis of gene expression as a strategy to identify connexin related gene networks. The huge amount of transcriptome data available in public databases, together with more sophisticated data processing tools, suggest that investigating transcriptional changes within a physiologically relevant "gap junction network" (GJN) will have wide application potential.

\section{MODULATION OF GAP JUNCTION COMMUNICATION}

The major cardiac connexin proteins are $\mathrm{Cx} 40$ (GJA5), Cx43 (GJA1), and Cx45 (GJC1), having distinct expression patterns and essential roles in propagation of action potentials, metabolic coupling, tissue homeostasis and heart development (Lo, 2000; Nishii et al., 2001; Rohr, 2004; Bernstein and Morley, 2006; Zacchigna et al., 2009; Jansen et al., 2010). Given these important functions, 
it is not surprising that GJC has been associated with various heart diseases (Jongsma and Wilders, 2000; Severs, 2001; Severs et al., 2004, 2008; Tribulová et al., 2008; Rodríguez-Sinovas et al., 2012; Verheule and Kaese, 2013). Here, we will focus on interacting and modulating proteins, clustered in functional groups, forming the basis for a draft GJN (Figure 1). A complete list of proteins, isoforms, and putative interactions in the GJN can be found in Table 1, a list of proven interactions in Table 2, while functional evidence is presented below. We will not discuss the structurally related, non-gap junction forming pannexins, or LRRC8 (Abascal and Zardoya, 2012), although it is interesting to note that pannexins release cardioprotectants during ischemic events in the heart (Wang et al., 2009; Vessey et al., 2010, 2011; Rodríguez-Sinovas et al., 2012).

\section{CELL-CELL JUNCTIONAL AND SCAFFOLDING PROTEINS}

A shared communality among connexins is the binding to junctional, scaffolding and cytoskeletal/transport proteins. Interactions between connexins and the tight junction proteins ZO-1, ZO-2, and ZO-3 (TJP1, TJP2, TJP3) vary regarding different connexin and ZO proteins (Giepmans and Moolenaar, 1998; Toyofuku et al., 1998; Kausalya et al., 2001), regulating connexon to gap junction transition (Rhett et al., 2011) and, as shown for $\mathrm{ZO}-1$, can be regulated by c-Src in cardiac myocytes (Toyofuku et al., 2001). Increased interaction of ZO-1 with $\mathrm{Cx} 43$ plays a role in $\mathrm{Cx} 43$ down-regulation and reduced $\mathrm{Cx} 43$ gap junction size in congestive heart failure (Bruce et al., 2008). Cell adhesion proteins like E-cadherin (CDH1) and $\alpha$-catenin are co-localized in newly formed gap junctions (Fujimoto et al., 1997), and E-cadherin mediated cell-cell contacts were shown to increase GJC (Jongen et al., 1991). p120 ctn (CTNND1) (Xu et al., 2001) and $\beta$-catenin (CTNNB1) (Ai et al., 2000) also co-localize with Cx43, and $\mathrm{Cx} 43$ was further found to immunoprecipitate with $\beta$-catenin ( $\mathrm{Li}$ et al., 2009). N-cadherin (CDH2)/connexin interactions were also reported (Li et al., 2009). CDH2 antibodies inhibit gap junction formation (Meyer et al., 1992), and cardiac specific CDH2 knockout in mice causes reduced GJC and sudden death (Li et al., 2005). Vinculin (VCL) interacts with connexins (Iacobas et al., 2007b), and cardiac myocyte specific VCL knockout caused Cx43 dislocation, dilated cardiomyopathy, and sudden death (Zemljic-Harpf et al., 2007). VCL also binds directly to ZO-1, stabilizing gap junctions in the heart (Zemljic-Harpf et al., 2014). The tight junction protein occludin (OCLN) was shown to interact with Cx32 (Kojima et al., 1999) and ZO-1 as well as ZO-2 (Furuse, 1994; Itoh et al., 1999).

AGS8 (FNDC1) forms a scaffold for $\mathrm{G}_{\beta \gamma}$ subunits and $\mathrm{Cx} 43$ and elicits phosphorylation and subsequent internalization, an effect involved in hypoxia-induced apoptosis in cardiomyocytes (Sato et al., 2009). In the brain, the scaffolding proteins MUPP1 (MPDZ) and AF6 (MLLT4) interact with Cx36 (Li et al., 2012). Membrane targeting, cellular migration and wound healing are modulated by $\mathrm{Cx} 43$ and interaction with the multidomain scaffolding protein CASK (Márquez-Rosado et al., 2012). Further, all three known human caveolins (CAV), a group of proteins found in lipid rafts and the membrane, interact with $\mathrm{Cx} 43$ (Langlois et al., 2008; Liu et al., 2010), increasing GJC (shown for CAV1 and CAV2). Drebrin (DBN1) interacts with Cx43 maintaining $\mathrm{Cx} 43$-containing gap junctions in their functional state (Butkevich et al., 2004), likely involving further interactions with the cytoskeleton.

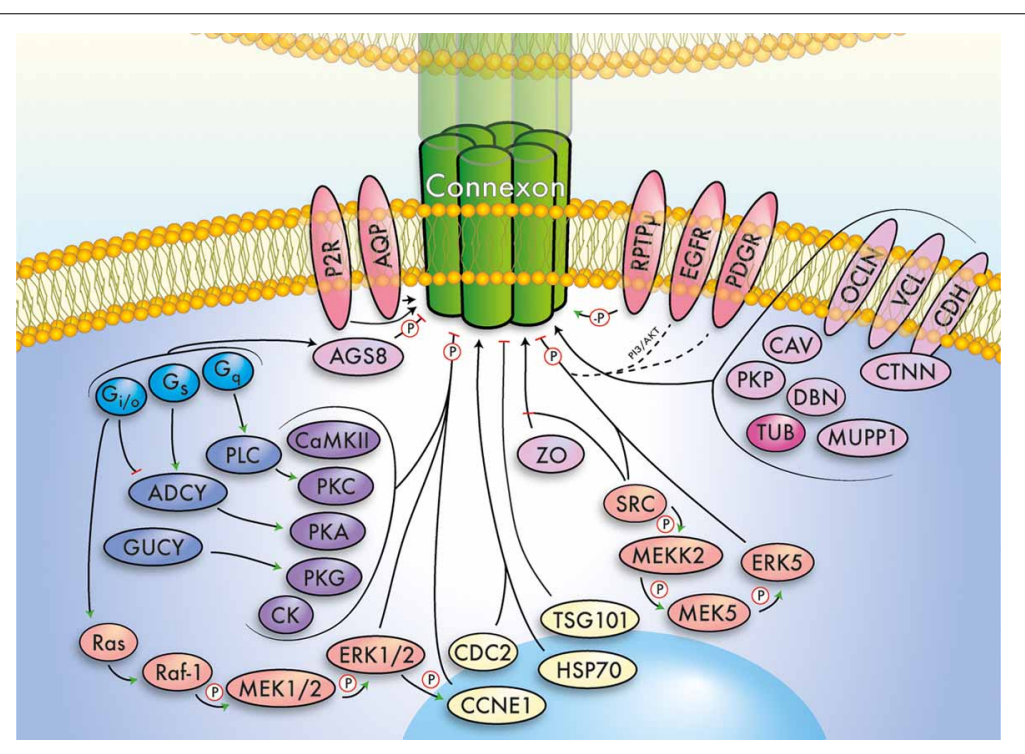

FIGURE 1 | Simplified summary of the gap junction network. This cartoon summarizes important signaling pathways, modulators, and interacting proteins of connexins, which converge exemplarily on a (green) connexin gap junction channel. The major functional groups outlined in the main text have been color-coded and relations between groups indicated by arrows. Further, phosphorylation (P) and dephosphorylation (-P) is highlighted. Note that the depicted pathways/interactions will vary for individual connexins. The gap junction network includes G proteins (light blue), cyclases (dark blue), kinases (violet), MAPK/ERK related signaling pathways (orange), receptors (red), scaffolding and junctional proteins (pink), cytoskeleton (dark pink), and cell cycle associated proteins (yellow). 
Table 1 | A draft of a gap junction network gene list.

ADCY1, ADCY10, ADCY2, ADCY3, ADCY4, ADCY5, ADCY6, ADCY7, ADCY8, ADCY9, AQP1, AQP2, AQP3, AQP4, AQP5, AQP6, AQP7, AQP8, AQP9, AQP10, AQP11, AQP12A, AQP12B, BAX, CALM1, CALM2, CALM3, CAMK1, CAMK1D, CAMK1G, CAMK2A, CAMK2B, CAMK2D, CAMK2G, CAMK4, CASK, CAV1, CAV2, CAV3, CCNE1, CDC2, CDH1, CDH10, CDH11, CDH12, CDH13, CDH14, CDH15, CDH16, CDH17, CDH18, CDH19, CDH2, CDH20, $\mathrm{CDH} 3, \mathrm{CDH} 4, \mathrm{CDH} 5, \mathrm{CDH} 6, \mathrm{CDH} 7, \mathrm{CDH} 8, \mathrm{CDH} 9, \mathrm{CIP} 85, \mathrm{CSNK} 1 \mathrm{~A} 1, \mathrm{CSNK} 1 \mathrm{~A} 1 \mathrm{~L}, \mathrm{CSNK} 1 \mathrm{D}, \mathrm{CSNK} 1 \mathrm{G} 1, \mathrm{CSNK} 1 \mathrm{G} 2, \mathrm{CSNK} 1 \mathrm{G} 3, \mathrm{CSNK} 2 \mathrm{~A} 1, \mathrm{CSNK} 2 \mathrm{~A} 2$, CSNK2B, CTNNA1, CTNNA2, CTNNA3, CTNNAL1, CTNNB1, CTNNBL1, CTNND1, CTNND2, DBN1, EGFR, GJA1, GJA10, GJA3, GJA4, GJA5, GJA8, GJA9, GJB1, GJB2, GJB3, GJB4, GJB5, GJB6, GJB7, GJC1, GJC2, GJC3, GJD2, GJD3, GJD4, GJE1, GNA11, GNA12, GNA13, GNA14, GNA15, GNAI1, GNAI2, GNAI3, GNAL, GNAO1, GNAQ, GNAS, GNAT1, GNAT2, GNAT3, GNAZ, GNB1, GNB1L, GNB2, GNB2L1, GNB3, GNB4, GNB5, GNG10, GNG11, GNG12, GNG13, GNG2, GNG3, GNG4, GNG5, GNG7, GNG8, GNGT1, GNGT2, GRB2, GUCY1A2, GUCY1A3, GUCY1B2, GUCY1B3, GUCY2A, GUCY2B, GUCY2C, GUCY2E, HRAS, HSP70-1A, HSP70RY, HSP70-4, HSP70-1B, HSP70T, HSP70-3, KRAS, MAP2K1, MAP2K2, MAP2K3, MAP2K4, MAP2K5, MAP2K6, MAP2K7, MAP3K1, MAP3K10, MAP3K11, MAP3K12, MAP3K13, MAP3K14, MAP3K15, MAP3K2, MAP3K3, MAP3K4, MAP3K5, MAP3K6, MAP3K7, MAP3K8, MAP3K9, MAP4K1, MAP4K2, MAP4K3, MAP4K4, MAP4K5, MAPK1, MAPK10, MAPK11, MAPK12, MAPK13, MAPK14, MAPK15, MAPK3, MAPK4, MAPK6, MAPK7, MAPK8, MAPK9, MLLT4, MPDZ, NRAS, OCLN, P2-receptor, P2RX7, P2RY1, PANX1, PANX2, PANX3, PDGFRA, PDGFRB, PDGFRL, PKP1, PKP2, PKP3, PKP4, PLCB1, PLCB2, PLCB3, PLCB4, PLCD1, PLCD3, PLCD4, PLCE1, PLCG1, PLCG2, PLCH1, PLCH2, PLCL1, PLCL2, PLCZ1, PRKAA1, PRKAA2, PRKAB1, PRKAB2, PRKACA, PRKACB, PRKACG, PRKAG1, PRKAG2, PRKAG3, PRKAR1A, PRKAR1B, PRKAR2A, PRKAR2B, PRKCA, PRKCB, PRKCD, PRKCDBP, PRKCE, PRKCG, PRKCH, PRKCI, PRKCQ, PRKCZ, PRKG1, PRKG2, PTPRM, RAF1, SOS1, SOS2, SRC, TJAP1, TJP1, TJP2, TJP3, TSG101, TUBA1A, TUBA1B, TUBA1C, TUBA3C, TUBA3D, TUBA3E, TUBA4A, TUBA8, TUBAL3, TUBB1, TUBB2A, TUBB2C, TUBB3, TUBB4, TUBB6, TUBD1, TUBE1, TUBG1, TUBG2, VCL

Summarizing GJC/connexin interaction/modulating proteins, we propose a draft of a GJN forming the blueprint to investigate the role of GJC. Known GJC modulators, as well as putative ones (isoforms and other closely related proteins) are included, with the intent to foster research on GJN modulation in health and disease.

\section{CYTOSKELETON}

Connexins are known to directly interact with $\alpha$-and $\beta$-tubulin (Giepmans et al., 2001a,b). There are multiple different tubulin subunits and regional differences in their expression may be linked to schizophrenia (Moehle et al., 2012). Direct interactions of connexins with actin were not reported, but connexins colocalize with actin, which was linked to anterograde Cx43 trafficking (Wall et al., 2007; Smyth et al., 2012). Interactions with actin can be mediated via various scaffolding proteins including drebrin (Butkevich et al., 2004; Majoul et al., 2007) and ZO-1 (Rhett et al., 2011). Further, Cx43 interacts with plakophilin-2 (PKP2) (Li et al., 2009; Sato et al., 2011), a protein linking cadherins to intermediate filaments in the cytoskeleton. Finally, expression of six cytoskeletal proteins (actin, tropomyosin, microtubule-associated protein RP/EB1, transgelin, GFAP, cofilin-1) were differentially regulated when Cx43 expression was targeted in astrocytes with small interfering (si)RNAs (Olk et al., 2010).

\section{KINASES}

Phosphorylation of connexins has various effects on GJC and plays major roles at several steps of the connexin lifecycle, including trafficking, assembly/disassembly, degradation, and gating (Lampe and Lau, 2004). PKA can phosphorylate connexins and promote their synthesis and assembly/stability (Imanaga et al., 2004; Ouyang et al., 2005; Zhang et al., 2005; Urschel et al., 2006; Liu et al., 2011a). PKCs (PRKC) modulate Cx43, including direct phosphorylation through PKCE (PRKCE), and increased phosphorylation mediated by PKC $\alpha$ (PRKCA) (Bowling et al., 2001). Further, PKC 8 (PRKCD) was shown to bind to Cx43 (Niger et al., 2010). PKCs are considered a therapeutic target due to the expression of multiple PKCs in the heart and their expression changes and contribution to heart diseases (Liu et al., 2009; Palaniyandi et al., 2009). The cGMP dependent Protein kinase G (cGK, PKG, PRKG) was also reported to phosphorylate connexins and modulate their expression (Kwak et al., 1995; Patel et al., 2006; Joshi et al., 2012). Mammals inherit two PRKGs, cGKI
(PRKG1), and cGKII (PRKG2), where PRKG1 is the main PRK in the heart. PRKG1 has well-known functions in the cardiovascular system, including excitation-contraction coupling, contractility, CM hypertrophic remodeling and more, where elevated cGMP levels protect against adverse ventricular remodeling (Balligand and Hammond, 2013; Frantz et al., 2013). In the failing human heart, PKA, as well as PKC and PKG, can phosphorylate cardiac ryanodine receptors, resulting in defective channel function due to increased sensitivity (Takasago et al., 1991; Marx et al., 2000). $\mathrm{Ca}^{2+} /$ calmodulin-dependent protein kinase II (CaMKII) can phosphorylate $\mathrm{Cx} 43$, and its activation and/or increased expression occurs in cardiac disease states like infarction, hypertrophy, and myocardial ischemia (see Erickson and Anderson, 2008; Huang et al., 2011 and references within) and is therefore considered a drug target in heart failure (Bers, 2010). The $\delta$ (CAMK2D) subunit is the highest expressed CaMKII in the heart, besides the $\gamma$ (CAMK2G) subunit being expressed at lower levels (Schworer et al., 1993; Edman and Schulman, 1994). Calmodulin (CaM) activates CaMKII, and also directly modulates connexin gating properties and mediating $\mathrm{Ca}^{2+}$-induced uncoupling of gap junctions (review: Zou et al., 2014). Connexins can be modulated by casein kinase 1 (CK1) and CK2 (Cheng and Louis, 1999; Yin, 2000). Besides the finding that CK1 $\delta$ (CSNK1D) regulates Cx43 gap junction assembly (Cooper and Lampe, 2002), little is known about which CKs targets for other connexins. CK2 $\alpha 1$ dependent phosphorylation may be involved in the development of cardiac hypertrophy (Eom et al., 2011).

\section{MAP KINASE SIGNALING CASCADES}

The mitogen-activated protein kinase (MAPK) cascades are key intracellular signaling pathways regulating diverse cellular functions such as proliferation, differentiation, survival, development, stress response, and apoptosis. Multiple MAPK cascades have been identified, and although often described as linear, they display significant cross talk (Keshet and Seger, 2010). In the heart, H-Ras, K-Ras, and N-Ras are expressed (Potenza et al., 2005). MAPKs have functions in heart development and are also 
Table 2 | Summary of connexin interacting proteins.

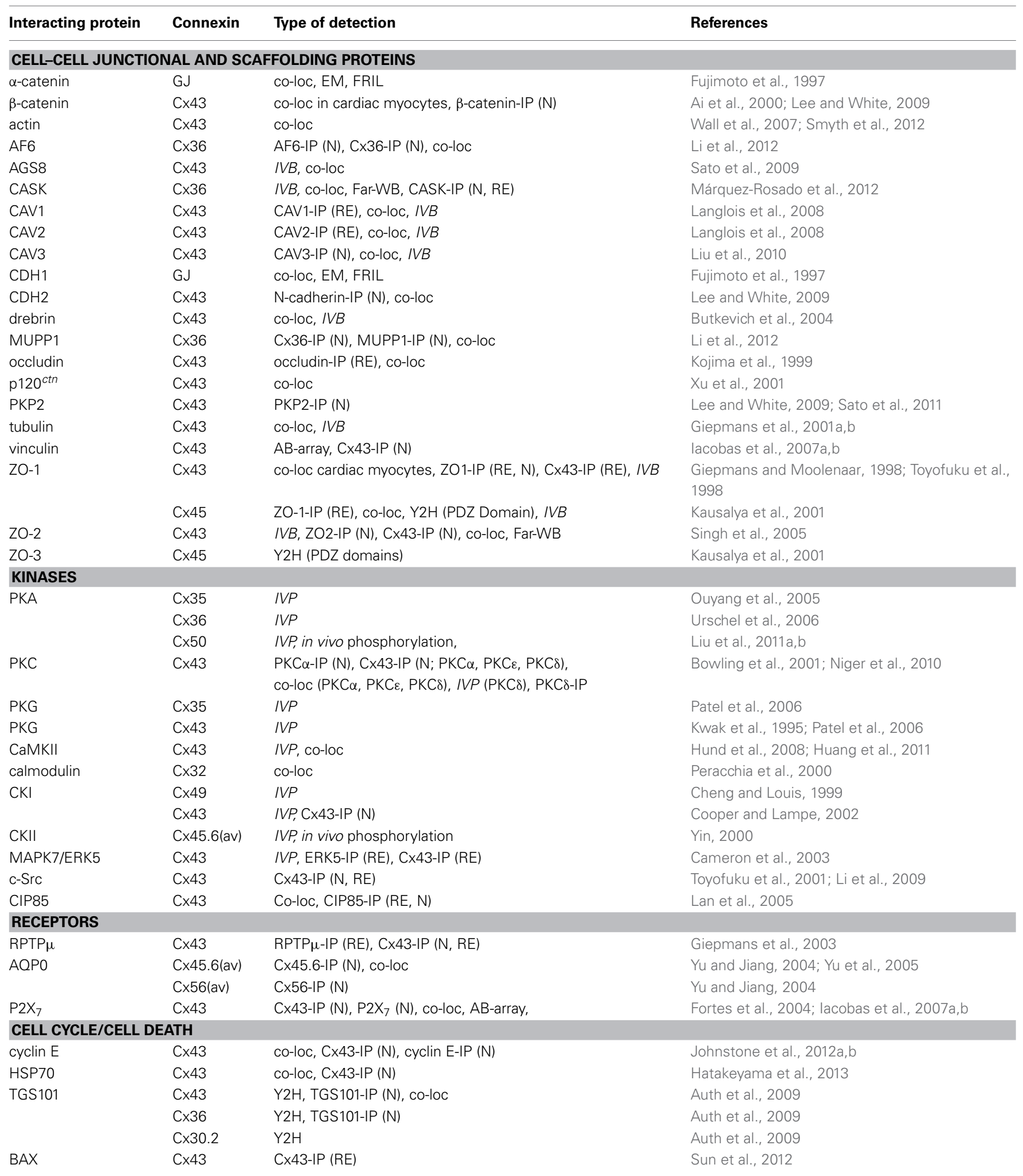

Summary of connexin interacting proteins. This table summarizes documented interactions described in the text and the detection methods used. It does not include indirect interactions with regulatory pathways. Abbreviations in alphabetic order: AB-array, antibody array; av, avian connexin; co-loc, co-localization in cells or tissues; IVB, in vitro binding, binding of peptides or functional domains; Far-WB, Far western blot; IVP, in vitro phosphorylation; N, native, non-transfected tissues, cells, or cell lines; RE, one or both IP partners were expressed in recombinant cells; $Y 2 H$, yeast two hybrid assay. 
involved in heart disease formation (Rose et al., 2010). MAPK phosphorylation of connexins is well-documented (reviews: Giepmans, 2004; Solan and Lampe, 2005), e.g., MAPK7/ERK5 was reported to phosphorylate and associate with $\mathrm{Cx} 43$, regulating gap junction uncoupling (Cameron et al., 2003). The non-receptor protein tyrosine kinase protein $\mathrm{c}$-Src inhibits the interaction of $\mathrm{Cx} 43$ and $\mathrm{ZO}-1$ in cardiac myocytes (Toyofuku et al., 2001). Further, c-Src activation was shown to inhibit gap junctional coupling and remodeling in ischemic heart disease (review: Giepmans, 2004; Rutledge et al., 2012). A Rab-GAP-like protein, CIP85, interacts with $\mathrm{Cx} 43$ and induce its internalization and degradation (Lan et al., 2005; Cochrane et al., 2013).

\section{HETEROTRIMERIC G-PROTEINS}

$G$ proteins can interact with GJC by their activation/inhibition of different signaling cascades, e.g., via adenylyl cyclase or phospholipase C (see below). General consent is that GNAI2 is the main $G_{i \alpha}$ in the heart, GNAI3 is expressed in lower amounts and GNAI1 is not expressed (Eschenhagen et al., 1992). However, there are few studies investigating expression of GNAI1 in detail. One newer study reports some cardiac GNAI1 expression (Dizayee et al., 2011) in the heart, alongside the knowledge of its expression in erythrocytes (Olearczyk et al., 2004) and thrombocytes (Patel et al., 2003). GNAI2 is thought to be up-regulated in various heart diseases, but maybe not in ischemic heart disease (ICM) (Feldman et al., 1988; Neumann et al., 1988; Böhm et al., 1990; Eschenhagen et al., 1992). Lack of $\mathrm{G}_{\alpha_{\mathrm{o}}}$ leads to tachycardia and defects in short-term heart rate dynamics (Zuberi et al., 2008). $G_{0}$ and $G_{i}$ may be involved in gap junction assembly, as pertussis toxin (PTX) sensitive G proteins were linked to Cx43 trafficking (Lampe et al., 2001). Overexpression of $\mathrm{G}_{\mathrm{s}}(\mathrm{GNAS})$ causes many features of dilated cardiomyopathy (DCM) (Iwase et al., 1997), and haplotypes causing different expression levels of $\mathrm{G}_{\mathrm{s}}$ have been found in humans (Frey et al., 2009), providing a putative link to heart disease risk. $\mathrm{G}_{\mathrm{q}}$ (GNAQ) overexpression leads to heart hypertrophy and contractile failure in transgenic mice (D'Angelo et al., 1997; Fan et al., 2005), and knockout prevents ventricular hypertrophy in response to pressure-overload (Wettschureck et al., 2001). $\mathrm{G}_{\alpha 13}$ regulates the expression of hypertrophic and fibrotic genes in cardiomyocytes, and inactivation prevents cardiac decompensation (Finn, 1999; Takefuji et al., 2012).

\section{CYCLASES AND PHOSPHOLIPASE C}

Modulators of the soluble guanylate cyclase (sGC, GUCY) are promising new drugs for heart failure treatment (Mitrovic et al., 2011). sGC is a heterodimer composed of one $\alpha$ (GUCYA), and one heme-binding $\beta$ domain (GUCYB), of which $s G C \alpha_{1} \beta_{1}$ is the principal heteromer in the heart (see Mitrovic et al., 2011 and references within). Adenylyl cyclase type III (ADCY) is considered a therapeutic target for heart diseases, where from 10 known ADCYs ADCY5 and ADCY6 are the predominant ones in the heart, expressed in a development-dependent way (e.g., Feldman, 2002 and references within), but several others are also expressed (Ludwig and Seuwen, 2002). Phospholipase C (PLC) cleaves phosphatidylinositol 4,5-bisphosphate $\left(\mathrm{PIP}_{2}\right)$ into DAG and inositol 1,4,5-trisphosphate $\left(\mathrm{IP}_{3}\right)$. DAG remains bound to the membrane, and $\mathrm{IP}_{3}$ is released as a soluble structure into the cytosol activating $\mathrm{IP}_{3}$ calcium channels in the smooth endoplasmic reticulum. In addition, calcium and DAG activate PKC. A majority of the 15 known PLCs is present in the heart and some were linked to heart dysfunction (Schwertz and Halverson, 1992; Meij et al., 1997; Hwang et al., 2004; Mangat et al., 2006; Ichise et al., 2009; Otaegui et al., 2010). PLC $\beta 3$ was reported to colocalize with $\mathrm{Cx} 43$, via the scaffolding protein $\mathrm{ZO}-1$ (see below), where localized changes in $\mathrm{PIP}_{2}$ levels dictate channel inhibition (Van Zeijl et al., 2007).

\section{RECEPTORS}

Connexins interact with various other membrane proteins. The receptor protein tyrosine phosphatase (PTP) family regulates a variety of cellular processes including cell growth, differentiation, and mitotic cycle. RPTP $\mu$ (PTPRM) can bind and possibly dephosphorylate $\mathrm{Cx} 43$, counteracting c-Src phosphorylation, and preventing channel closure (Giepmans et al., 2003). The epidermal growth factor receptor (EGFR) is a receptor tyrosine kinase of the ErbB family. EGFR activation led to connexin phosphorylation and increased cytosolic localization of $\mathrm{Cx} 43$ possibly via the PI3/Akt signaling pathway (Díez et al., 1998; Abdelmohsen et al., 2003; Dubé et al., 2012). Platelet-derived growth factor receptors (PDGFRs) are receptors with intracellular tyrosine kinase activity, initiating intracellular signaling through the MAPK, PI3K, and PKC $\gamma$ pathways. PDGFR activation was shown to lead to $\mathrm{Cx} 43$ phosphorylation by MAPK signaling (Hossain et al., 1999a,b, 1998a,b; Shen et al., 2013). PDGFRs have a vital role to loadinduced cardiac stress response, angiogenesis, and regeneration (Schatteman et al., 1995; Van den Akker et al., 2008; Bleyl et al., 2010; Chintalgattu et al., 2010; Kim et al., 2010; Chong et al., 2013). The cystic fibrosis transmembrane conductance regulator (CFTR) regulates GJC possibly via a complex mechanism involving $\mathrm{c}$-Src, modulating voltage sensitivity and gating. Further, functional interaction of gap junctions, CFTR and glutamate receptors (GluRs) were reported, although the molecular mechanism is unclear (review: Chanson et al., 2007). GluRs were found in the human myocardium, conducting system, nerve fibers, and intramural ganglia cells (Gill et al., 2007), and glutamate changes intracellular calcium oscillations in cultured rat myocardial cells (Winter and Baker, 1995). Together, GluRs are likely to play a physiological role in heart functions including contraction and rhythm, although their precise role is still elusive. Various aquaporins (AQP) are expressed in the heart, and although the information available is still limited, they were reported to mediate water flux across endothelial membranes, modulate calcium signaling, and nutrient delivery to the heart (Rutkovskiy et al., 2013). AQP0 was shown to interact with gap junctions and in particular with Cx50 in differentiating lens fibers (Yu and Jiang, 2004), enhancing gap junctional coupling (Liu et al., 2011b), suggesting a putative role for $\mathrm{AQP} /$ connexin interactions in the heart. Finally, interactions between connexins and purinergic receptors provide an interesting link of connexins to ATP signaling (Fortes et al., 2004; Iacobas et al., 2007b).

\section{CELL CYCLE/CELL DEATH}

Beyond interactions at the plasma membrane and cytosol, connexins can interact with proteins shuttling between cytoplasm and nucleus, or proteins located in mitochondria. Cx43 interacts 
with cyclin E (CCNE1), for example after MAPK phosphorylation, promoting smooth muscle cell proliferation (Johnstone et al., 2012b). Cx43 also competes with cyclin D1 for binding to heat shock protein 70 (HSP70) (Hatakeyama et al., 2013). Further, degradation of connexins was linked to binding to tumor susceptibility gene 101 (TSG101), an ubiquitinconjugating enzyme associated with the cell cycle, turnover of proteins, and transcriptional regulation (Auth et al., 2009). Cyclin-dependent kinase 2 (CDC2) was shown to phosphorylate Cx43 in a cell-cycle dependent manner (Kanemitsu et al., 1998; Lampe et al., 1998). Connexins also interact with BAX, a member of the Bcl-2 protein family located in the outer mitochondrial membrane, to regulate apoptosis (Sun et al., 2012).

\section{FUTURE DIRECTIONS: TOWARD META-ANALYSIS OF THE GAP JUNCTION NETWORK?}

Experimental investigation of the GJN is challenging, due to the large number of putative interactions, procedural issues or the huge experimental variations caused by small sample sizes frequently found in studies using human tissues. However, meta-analyses can capitalize from the growing number of multiple microarray and other "-omics" studies publicly available. Technically, different approaches to merge and perform a statistical analysis have been established and various software tools allow users to process microarray data (Saeed et al., 2003; Gentleman et al., 2004; Reich et al., 2006; Tseng et al., 2012; Xia et al., 2013). Unfortunately, cross-comparison of studies is still a major challenge, but the recently developed online platform INMEX (Xia et al., 2013), or a LabVIEW-based software tool called Array Data Extractor (ADE) (Kurtenbach et al., 2013) are efforts toward making microarray data available in a user-friendly way to a large community. This opens the opportunity to test physiologically relevant changes of the proposed GJN in health and disease.

\section{ACKNOWLEDGMENTS}

This work was supported by CIHR/CRC and NSERC DG programs.

\section{REFERENCES}

Abascal, F., and Zardoya, R. (2012). LRRC8 proteins share a common ancestor with pannexins, and may form hexameric channels involved in cell-cell communication. Bioessays 34, 551-560. doi: 10.1002/bies.201100173

Abdelmohsen, K., Gerber, P. A., von Montfort, C., Sies, H., and Klotz, L.-O. (2003). Epidermal growth factor receptor is a common mediator of quinoneinduced signaling leading to phosphorylation of connexin-43: role of glutathione and tyrosine phosphatases. J. Biol. Chem. 278, 38360-38367. doi: 10.1074/jbc.M306785200

Ai, Z., Fischer, A., Spray, D. C., Brown, A. M., and Fishman, G. I. (2000). Wnt-1 regulation of connexin43 in cardiac myocytes. J. Clin. Invest. 105, 161-171. doi: $10.1172 / J C I 7798$

Aleksic, B., Ishihara, R., Takahashi, N., Maeno, N., Ji, X., Saito, S., et al. (2007). Gap junction coding genes and schizophrenia: a genetic association study. J. Hum. Genet. 52, 498-501. doi: 10.1007/s10038-007-0142-5

Anselmi, F., Hernandez, V. H., Crispino, G., Seydel, A., Ortolano, S., Roper, S. D., et al. (2008). ATP release through connexin hemichannels and gap junction transfer of second messengers propagate $\mathrm{Ca}^{2+}$ signals across the inner ear. Proc. Natl. Acad. Sci. U.S.A. 105, 18770-18775. doi: 10.1073/pnas.0800793105

Auth, T., Schlüter, S., Urschel, S., Kussmann, P., Sonntag, S., Höher, T., et al. (2009). The TSG101 protein binds to connexins and is involved in connexin degradation. Exp. Cell Res. 315, 1053-1062. doi: 10.1016/j.yexcr.2008.12.025
Balligand, J.-L., and Hammond, J. (2013). Protein kinase G type I in cardiac myocytes: unmasked at last? Eur. Heart J. 34, 1181-1185. doi: 10.1093/eurheartj/ehr415

Bernstein, S. A., and Morley, G. E. (2006). Gap junctions and propagation of the cardiac action potential. Adv. Cardiol. 42, 71-85. doi: 10.1159/000092563

Bers, D. M. (2010). CaMKII inhibition in heart failure makes jump to human. Circ. Res. 107, 1044-1046. doi: 10.1161/CIRCRESAHA.110.231902

Bleyl, S. B., Saijoh, Y., Bax, N. A. M., Gittenberger-de Groot, A. C., Wisse, L. J., Chapman, S. C., et al. (2010). Dysregulation of the PDGFRA gene causes inflow tract anomalies including TAPVR: integrating evidence from human genetics and model organisms. Hum. Mol. Genet. 19, 1286-1301. doi: 10.1093/hmg/ddq005

Böhm, M., Gierschik, P., Jakobs, K. H., Pieske, B., Schnabel, P., Ungerer, M., et al. (1990). Increase of Gi alpha in human hearts with dilated but not ischemic cardiomyopathy. Circulation 82, 1249-1265.

Bowling, N., Huang, X., Sandusky, G. E., Fouts, R. L., Mintze, K., Esterman, M., et al. (2001). Protein kinase C-alpha and -epsilon modulate connexin43 phosphorylation in human heart. J. Mol. Cell. Cardiol. 33, 789-798. doi: 10.1006/jmcc.2000.1349

Bruce, A. F., Rothery, S., Dupont, E., and Severs, N. J. (2008). Gap junction remodelling in human heart failure is associated with increased interaction of connexin 43 with ZO-1. Cardiovasc. Res. 77, 757-765. doi: 10.1093/cvr/cvm083

Bruzzone, S., Guida, L., Zocchi, E., Franco, L., and De Flora A. (2001). Connexin 43 hemi channels mediate $\mathrm{Ca} 2+$-regulated transmembrane $\mathrm{NAD}+$ fluxes in intact cells. FASEB J. 15, 10-12. doi: 10.1096/fj.00-0566fje

Butkevich, E., Hülsmann, S., Wenzel, D., Shirao, T., Duden, R., and Majoul, I. (2004). Drebrin is a novel connexin-43 binding partner that links gap junctions to the submembrane cytoskeleton. Curr. Biol. 14, 650-658. doi: 10.1016/j.cub.2004.03.063

Cameron, S. J., Malik, S., Akaike, M., Lerner-Marmarosh, N., Yan, C., Lee, J.D., et al. (2003). Regulation of epidermal growth factor-induced connexin 43 gap junction communication by big mitogen-activated protein kinase1/ERK5 but not ERK1/2 kinase activation. J. Biol. Chem. 278, 18682-18688. doi: 10.1074/jbc.M213283200

Chanson, M., Kotsias, B. A., Peracchia, C., and O'Grady, S. M. (2007). Interactions of connexins with other membrane channels and transporters. Prog. Biophys. Mol. Biol. 94, 233-244. doi: 10.1016/j.pbiomolbio.2007.03.002

Cheng, H. L., and Louis, C. F. (1999). Endogenous casein kinase I catalyzes the phosphorylation of the lens fiber cell connexin49. Eur. J. Biochem. 263, 276-286. doi: 10.1046/j.1432-1327.1999.00502.x

Chintalgattu, V., Ai, D., Langley, R. R., Zhang, J., Bankson, J. A., Shih, T. L., et al. (2010). Cardiomyocyte PDGFR-beta signaling is an essential component of the mouse cardiac response to load-induced stress. J. Clin. Invest. 120, 472-484. doi: $10.1172 / \mathrm{JCI} 39434$

Chong, J. J. H., Reinecke, H., Iwata, M., Torok-Storb, B., Stempien-Otero, A., and Murry, C. E. (2013). Progenitor cells identified by PDGFR-alpha expression in the developing and diseased human heart. Stem Cells Dev. 22, 1932-1943. doi: $10.1089 /$ scd.2012.0542

Cochrane, K., Su, V., and Lau, A. F. (2013). The connexin43-interacting protein, CIP85, mediates the internalization of connexin 43 from the plasma membrane. Cell Commun. Adhes. 20, 53-66. doi: 10.3109/15419061. 2013.784745

Contreras, J. E., Sánchez, H. A., Véliz, L. P., Bukauskas, F. F., Bennett, M. V. L., and Sáez, J. C. (2004). Role of connexin-based gap junction channels and hemichannels in ischemia-induced cell death in nervous tissue. Brain Res. Brain Res. Rev. 47, 290-303. doi: 10.1016/j.brainresrev.2004.08.002

Cooper, C. D., and Lampe, P. D. (2002). Casein kinase 1 regulates connexin43 gap junction assembly. J. Biol. Chem. 277, 44962-44968. doi 10.1074/jbc.M209427200

D’Angelo, D. D., Sakata, Y., Lorenz, J. N., Boivin, G. P., Walsh, R. A., Liggett, S. B., et al. (1997). Transgenic Galphaq overexpression induces cardiac contractile failure in mice. Proc. Natl. Acad. Sci. U.S.A. 94, 8121-8126.

Díez, J. A., Elvira, M., and Villalobo, A. (1998). The epidermal growth factor receptor tyrosine kinase phosphorylates connexin32. Mol. Cell. Biochem. 187, 201-210. doi: 10.1023/A:1006884600724

Dizayee, S., Kaestner, S., Kuck, F., Hein, P., Klein, C., Piekorz, R. P., et al. (2011). Gai2- and Gai3-specific regulation of voltage-dependent L-type calcium channels in cardiomyocytes. PLOS ONE 6:e24979. doi: 10.1371/journal.pone.0024979 
Dubé, E., Dufresne, J., Chan, P. T. K., and Cyr, D. G. (2012). Epidermal growth factor regulates connexin 43 in the human epididymis: role of gap junctions in azoospermia. Hum. Reprod. 27, 2285-2296. doi: 10.1093/humrep/des164

Edman, C. F., and Schulman, H. (1994). Identification and characterization of delta B-CaM kinase and delta C-CaM kinase from rat heart, two new multifunctional $\mathrm{Ca}^{2+} /$ calmodulin-dependent protein kinase isoforms. Biochim. Biophys. Acta 1221, 89-101.

Eom, G. H., Cho, Y. K., Ko, J.-H., Shin, S., Choe, N., Kim, Y., et al. (2011). Casein kinase-2 $\alpha 1$ induces hypertrophic response by phosphorylation of histone deacetylase $2 \mathrm{~S} 394$ and its activation in the heart. Circulation 123, 2392-2403. doi: 10.1161/CIRCULATIONAHA.110.003665

Erickson, J. R., and Anderson, M. E. (2008). CaMKII and its role in cardiac arrhythmia. J. Cardiovasc. Electrophysiol. 19, 1332-1336. doi: 10.1111/j.15408167.2008.01295.x

Eschenhagen, T., Mende, U., Nose, M., Schmitz, W., Scholz, H., Haverich, A., et al. (1992). Increased messenger RNA level of the inhibitory $G$ protein alpha subunit Gi alpha-2 in human end-stage heart failure. Circ. Res. 70, 688-696. doi: 10.1161/01.RES.70.4.688

Fan, G., Jiang, Y.-P., Lu, Z., Martin, D. W., Kelly, D. J., Zuckerman, J. M., et al. (2005). A transgenic mouse model of heart failure using inducible Galpha q. J. Biol. Chem. 280, 40337-40346. doi: 10.1074/jbc.M506810200

Fatemi, S. H., Folsom, T. D., Reutiman, T. J., and Lee, S. (2008). Expression of astrocytic markers aquaporin 4 and connexin 43 is altered in brains of subjects with autism. Synapse 62, 501-507. doi: 10.1002/syn.20519

Feldman, A. M. (2002). Adenylyl cyclase: a new target for heart failure therapeutics. Circulation 105, 1876-1878. doi: 10.1161/01.CIR.0000016965.24080.12

Feldman, A. M., Cates, A. E., Veazey, W. B., Hershberger, R. E., Bristow, M. R., Baughman, K. L., et al. (1988). Increase of the 40,000-mol wt pertussis toxin substrate ( $\mathrm{G}$ protein) in the failing human heart. J. Clin. Invest. 82, 189-197. doi: $10.1172 / J C I 113569$

Finegold, D. N., Baty, C. J., Knickelbein, K. Z., Perschke, S., Noon, S. E., Campbell, D., et al. (2012). Connexin 47 mutations increase risk for secondary lymphedema following breast cancer treatment. Clin. Cancer Res. 18, 2382-2390. doi: 10.1158/1078-0432.CCR-11-2303

Finn, S. (1999). G $\alpha 13$ stimulates gene expression and increases cell size in cultured neonatal rat ventricular myocytes. Cardiovasc. Res. 42, 140-148. doi: 10.1016/S0008-6363(98)00294-6

Fong, J. T., Kells, R. M., Gumpert, A. M., Marzillier, J. Y., Davidson, M. W., and Falk, M. M. (2012). Internalized gap junctions are degraded by autophagy. Autophagy 8, 794-811. doi: 10.4161/auto.19390

Fortes, F. S. A., Pecora, I. L., Persechini, P. M., Hurtado, S., Costa, V., Coutinho-Silva, R., et al. (2004). Modulation of intercellular communication in macrophages: possible interactions between GAP junctions and P2 receptors. J. Cell Sci. 117, 4717-4726. doi: 10.1242/jcs.01345

Frantseva, M. V., Kokarovtseva, L., Naus, C. G., Carlen, P. L., MacFabe, D., and Perez Velazquez, J. L. (2002). Specific gap junctions enhance the neuronal vulnerability to brain traumatic injury. J. Neurosci. 22, 644-653.

Frantz, S., Klaiber, M., Baba, H. A., Oberwinkler, H., Völker, K., Gaßner, B., et al. (2013). Stress-dependent dilated cardiomyopathy in mice with cardiomyocyterestricted inactivation of cyclic GMP-dependent protein kinase I. Eur. Heart J. 34, 1233-1244. doi: 10.1093/eurheartj/ehr445

Frey, U. H., Adamzik, M., Kottenberg-Assenmacher, E., Jakob, H., Manthey, I., Broecker-Preuss, M., et al. (2009). A novel functional haplotype in the human GNAS gene alters Galphas expression, responsiveness to betaadrenoceptor stimulation, and peri-operative cardiac performance. Eur. Heart J. 30, 1402-1410. doi: 10.1093/eurheartj/ehn572

Fujimoto, K., Nagafuchi, A., Tsukita, S., Kuraoka, A., Ohokuma, A., and Shibata, Y. (1997). Dynamics of connexins, E-cadherin and alpha-catenin on cell membranes during gap junction formation. J. Cell Sci. 110(pt 3), 311-322.

Furuse, M. (1994). Direct association of occludin with ZO-1 and its possible involvement in the localization of occludin at tight junctions. J. Cell Biol. 127, 1617-1626. doi: 10.1083/jcb.127.6.1617

Gajda, Z., Szupera, Z., Blazsó, G., and Szente, M. (2005). Quinine, a blocker of neuronal cx36 channels, suppresses seizure activity in rat neocortex in vivo. Epilepsia 46, 1581-1591. doi: 10.1111/j.1528-1167.2005.00254.x

Garré, J. M., Retamal, M. A., Cassina, P., Barbeito, L., Bukauskas, F. F., Sáez, J. C., et al. (2010). FGF-1 induces ATP release from spinal astrocytes in culture and opens pannexin and connexin hemichannels. Proc. Natl. Acad. Sci. U.S.A. 107, 22659-22664. doi: 10.1073/pnas.1013793107
Gentleman, R. C., Carey, V. J., Bates, D. M., Bolstad, B., Dettling, M., Dudoit, S., et al. (2004). Bioconductor: open software development for computational biology and bioinformatics. Genome Biol. 5, R80. doi: 10.1186/gb-2004-5-10-r80

Giepmans, B. N. G. (2004). Gap junctions and connexin-interacting proteins. Cardiovasc. Res. 62, 233-245. doi: 10.1016/j.cardiores.2003.12.009

Giepmans, B. N. G., Feiken, E., Gebbink, M. F. B. G., and Moolenaar, W. H. (2003). Association of connexin 43 with a receptor protein tyrosine phosphatase. Cell Commun. Adhes. 10, 201-205. doi: 10.1080/714040427

Giepmans, B. N., and Moolenaar, W. H. (1998). The gap junction protein connexin43 interacts with the second PDZ domain of the zona occludens-1 protein. Curr. Biol. 8, 931-934. doi: 10.1016/S0960-9822(07)00375-2

Giepmans, B. N., Verlaan, I., Hengeveld, T., Janssen, H., Calafat, J., Falk, M. M., et al. (2001a). Gap junction protein connexin- 43 interacts directly with microtubules. Curr. Biol. 11, 1364-1368. doi: 10.1016/S0960-9822(01)00424-9

Giepmans, B. N., Verlaan, I., and Moolenaar, W. H. (2001b). Connexin-43 interactions with ZO-1 and alpha- and beta-tubulin. Cell Commun. Adhes. 8, 219-223. doi: 10.3109/15419060109080727

Gill, S., Veinot, J., Kavanagh, M., and Pulido, O. (2007). Human heart glutamate receptors - implications for toxicology, food safety, and drug discovery. Toxicol. Pathol. 35, 411-417. doi: 10.1080/01926230701230361

Grosely, R., and Sorgen, P. L. (2013). A history of gap junction structure: hexagonal arrays to atomic resolution. Cell Commun. Adhes. 20, 11-20. doi: 10.3109/15419061.2013.775256

Hatakeyama, T., Dai, P., Harada, Y., Hino, H., Tsukahara, F., Maru, Y., et al. (2013). Connexin 43 functions as a novel interacting partner of heat shock cognate protein 70. Sci. Rep. 3, 2719. doi: 10.1038/srep02719

Hossain, M. Z., Ao, P., and Boynton, A. L. (1998a). Platelet-derived growth factor-induced disruption of gap junctional communication and phosphorylation of connexin43 involves protein kinase $\mathrm{C}$ and mitogen-activated protein kinase. J. Cell. Physiol. 176, 332-341. doi: 10.1002/(SICI)10974652(199808) 176:2<332::AID-JCP11>3.0.CO;2-5

Hossain, M. Z., Ao, P., and Boynton, A. L. (1998b). Rapid disruption of gap junctional communication and phosphorylation of connexin 43 by plateletderived growth factor in T51B rat liver epithelial cells expressing platelet-derived growth factor receptor. J. Cell. Physiol. 174, 66-77. doi: 10.1002/(SICI)10974652(199801) 174:1<66::AID-JCP8>3.0.CO;2-E

Hossain, M. Z., Jagdale, A. B., Ao, P., and Boynton, A. L. (1999a). Mitogenactivated protein kinase and phosphorylation of connexin 43 are not sufficient for the disruption of gap junctional communication by platelet-derived growth factor and tetradecanoylphorbol acetate. J. Cell. Physiol. 179, 87-96. doi: 10.1002/(SICI) 1097-4652(199904)179:1<87::AID-JCP11>3.0.CO;2-K

Hossain, M. Z., Jagdale, A. B., Ao, P., Kazlauskas, A., and Boynton, A. L. (1999b). Disruption of gap junctional communication by the platelet-derived growth factor is mediated via multiple signaling pathways. J. Biol. Chem. 274, 10489-10496. doi: 10.1074/jbc.274.15.10489

Huang, R. Y.-C., Laing, J. G., Kanter, E. M., Berthoud, V. M., Bao, M., Rohrs, H. W., et al. (2011). Identification of CaMKII phosphorylation sites in Connexin43 by high-resolution mass spectrometry. J. Proteome Res. 10, 1098-1109. doi: $10.1021 / \mathrm{pr} 1008702$

Huang, T., Shao, Q., MacDonald, A., Xin, L., Lorentz, R., Bai, D., et al. (2013). Autosomal recessive GJA1 (Cx43) gene mutations cause oculodentodigital dysplasia by distinct mechanisms. J. Cell Sci. 126, 2857-2866. doi: $10.1242 /$ jcs. 123315

Hund, T. J., Decker, K. F., Kanter, E., Mohler, P. J., Boyden, P. A., Schuessler, R. B., et al. (2008). Role of activated CaMKII in abnormal calcium homeostasis and $\mathrm{I}(\mathrm{Na})$ remodeling after myocardial infarction: insights from mathematical modeling. J. Mol. Cell. Cardiol. 45, 420-428. doi: 10.1016/j.yjmcc. 2008.06.007

Hwang, K.-C., Lim, S., Kwon, H. M., Bae, Y. S., Kang, S.-M., Chung, K.-H., et al. (2004). Phospholipase C-deltal rescues intracellular $\mathrm{Ca}^{2+}$ overload in ischemic heart and hypoxic neonatal cardiomyocytes. J. Steroid Biochem. Mol. Biol. 91, 131-138. doi: 10.1016/j.jsbmb.2004.02.009

Iacobas, D. A., Iacobas, S., and Spray, D. C. (2007a). Connexin-dependent transcellular transcriptomic networks in mouse brain. Prog. Biophys. Mol. Biol. 94, 169-185. doi: 10.1016/j.pbiomolbio.2007.03.015

Iacobas, D. A., Suadicani, S. O., Iacobas, S., Chrisman, C., Cohen, M. A., Spray, D. C., et al. (2007b). Gap junction and purinergic P2 receptor proteins as a functional unit: insights from transcriptomics. J. Membr. Biol. 217, 83-91. doi: $10.1007 /$ s00232-007-9039-7 
Iacobas, S., Iacobas, D. A., Spray, D. C., and Scemes, E. (2012). The connexin43dependent transcriptome during brain development: importance of genetic background. Brain Res. 1487, 131-139. doi: 10.1016/j.brainres.2012.05.062

Ichise, H., Ichise, T., Ohtani, O., and Yoshida, N. (2009). Phospholipase Cgamma2 is necessary for separation of blood and lymphatic vasculature in mice. Development 136, 191-195. doi: 10.1242/dev.025353

Imanaga, I., Hai, L., Ogawa, K., Matsumura, K., and Mayama, T. (2004). Phosphorylation of connexin in functional regulation of the cardiac gap junction. Exp. Clin. Cardiol. 9, 161-164.

Itoh, M., Morita, K., and Tsukita, S. (1999). Characterization of ZO-2 as a MAGUK family member associated with tight as well as adherens junctions with a binding affinity to occludin and alpha catenin. J. Biol. Chem. 274, 5981-5986.

Iwase, M., Uechi, M., Vatner, D. E., Asai, K., Shannon, R. P., Kudej, R. K., et al. (1997). Cardiomyopathy induced by cardiac Gs alpha overexpression. Am. J. Physiol. 272, H585-H589.

Jansen, J. A., van Veen, T. A. B., de Bakker, J. M. T., and van Rijen, H. V. M. (2010). Cardiac connexins and impulse propagation. J. Mol. Cell. Cardiol. 48, 76-82. doi: 10.1016/j.yjmcc.2009.08.018

Johnstone, S. R., Billaud, M., Lohman, A. W., Taddeo, E. P., and Isakson, B. E. (2012a). Posttranslational modifications in connexins and pannexins. J. Membr. Biol. 245, 319-332. doi: 10.1007/s00232-012-9453-3

Johnstone, S. R., Kroncke, B. M., Straub, A. C., Best, A. K., Dunn, C. A., Mitchell, L. A., et al. (2012b). MAPK phosphorylation of connexin 43 promotes binding of cyclin E and smooth muscle cell proliferation. Circ. Res. 111, 201-211. doi: 10.1161/CIRCRESAHA.112.272302

Jongen, W. M., Fitzgerald, D. J., Asamoto, M., Piccoli, C., Slaga, T. J., Gros, D., et al. (1991). Regulation of connexin 43-mediated gap junctional intercellular communication by $\mathrm{Ca} 2+$ in mouse epidermal cells is controlled by E-cadherin. J. Cell Biol. 114, 545-555. doi: 10.1083/jcb.114.3.545

Jongsma, H. J., and Wilders, R. (2000). Gap Junctions in Cardiovascular Disease. Circ. Res. 86, 1193-1197. doi: 10.1161/01.RES.86.12.1193

Joshi, C. N., Martin, D. N., Shaver, P., Madamanchi, C., Muller-Borer, B. J., and Tulis, D. A. (2012). Control of vascular smooth muscle cell growth by connexin 43. Front. Physiol. 3:220. doi: 10.3389/fphys.2012.00220

Kameritsch, P., Pogoda, K., and Pohl, U. (2012). Channel-independent influence of connexin 43 on cell migration. Biochim. Biophys. Acta 1818, 1993-2001. doi: 10.1016/j.bbamem.2011.11.016

Kanemitsu, M. Y., Jiang, W., and Eckhart, W. (1998). Cdc2-mediated phosphorylation of the gap junction protein, connexin43, during mitosis. Cell Growth Differ. 9, 13-21.

Kausalya, P. J., Reichert, M., and Hunziker, W. (2001). Connexin45 directly binds to ZO-1 and localizes to the tight junction region in epithelial MDCK cells. FEBS Lett. 505, 92-96. doi: 10.1016/S0014-5793(01)02786-7

Keshet, Y., and Seger, R. (2010). The MAP kinase signaling cascades: a system of hundreds of components regulates a diverse array of physiological functions. Methods Mol. Biol. 661, 3-38. doi: 10.1007/978-1-60761-795-2_1

Kim, J., Wu, Q., Zhang, Y., Wiens, K. M., Huang, Y., Rubin, N., et al. (2010). PDGF signaling is required for epicardial function and blood vessel formation in regenerating zebrafish hearts. Proc. Natl. Acad. Sci. U.S.A. 107, 17206-17210. doi: 10.1073/pnas.0915016107

Kleopa, K. A., Orthmann-Murphy, J., and Sargiannidou, I. (2010). Gap junction disorders of myelinating cells. Rev. Neurosci. 21, 397-419. doi: 10.1515/REVNEURO.2010.21.5.397

Kojima, T., Sawada, N., Chiba, H., Kokai, Y., Yamamoto, M., Urban, M., et al. (1999). Induction of tight junctions in human connexin 32 (hCx32)-transfected mouse hepatocytes: connexin 32 interacts with occludin. Biochem. Biophys. Res. Commun. 266, 222-229. doi: 10.1006/bbrc.1999.1778

Kurtenbach, S., Kurtenbach, S., and Zoidl, G. (2013). Array data extractor (ADE): a LabVIEW program to extract and merge gene array data. BMC Res. Notes 6:496. doi: 10.1186/1756-0500-6-496

Kwak, B. R., Sáez, J. C., Wilders, R., Chanson, M., Fishman, G. I., Hertzberg, E. L., et al. (1995). Effects of cGMP-dependent phosphorylation on rat and human connexin43 gap junction channels. Pflugers Arch. 430, 770-778. doi: 10.1007/BF00386175

Laird, D. W. (2006). Life cycle of connexins in health and disease. Biochem. J. 394, 527-543. doi: 10.1042/BJ20051922

Lampe, P. D., Kurata, W. E., Warn-Cramer, B. J., and Lau, A. F. (1998). Formation of a distinct connexin 43 phosphoisoform in mitotic cells is dependent upon p34cdc2 kinase. J. Cell Sci. 111(pt 6), 833-841.
Lampe, P. D., and Lau, A. F. (2004). The effects of connexin phosphorylation on gap junctional communication. Int. J. Biochem. Cell Biol. 36, 1171-1186. doi: 10.1016/S1357-2725(03)00264-4

Lampe, P. D., Qiu, Q., Meyer, R. A., TenBroek, E. M., Walseth, T. F., Starich, T. A., et al. (2001). Gap junction assembly: PTX-sensitive G proteins regulate the distribution of connexin43 within cells. Am. J. Physiol. Cell Physiol. 281, C1211-C1222.

Lan, Z., Kurata, W. E., Martyn, K. D., Jin, C., and Lau, A. F. (2005). Novel rab GAPlike protein, CIP85, interacts with connexin43 and induces its degradation. Biochemistry 44, 2385-2396. doi: 10.1021/bi048306w

Langlois, S., Cowan, K. N., Shao, Q., Cowan, B. J., and Laird, D. W. (2008). Caveolin-1 and -2 interact with connexin43 and regulate gap junctional intercellular communication in keratinocytes. Mol. Biol. Cell 19, 912-928. doi: 10.1091/mbc.E07-06-0596

Lee, J. R., and White, T. W. (2009). Connexin-26 mutations in deafness and skin disease. Expert Rev. Mol. Med. 11, e35. doi: 10.1017/S1462399409001276

Li, J., Patel, V. V., Kostetskii, I., Xiong, Y., Chu, A. F., Jacobson, J. T., et al. (2005). Cardiac-specific loss of N-cadherin leads to alteration in connexins with conduction slowing and arrhythmogenesis. Circ. Res. 97, 474-481. doi: 10.1161/01.RES.0000181132.11393.18

Li, J., Shen, H., Naus, C. C., Zhang, L., and Carlen, P. L. (2001). Upregulation of gap junction connexin 32 with epileptiform activity in the isolated mouse hippocampus. Neuroscience 105, 589-598. doi: 10.1016/S0306-4522(01)00204-4

Li, M. W. M., Mruk, D. D., Lee, W. M., and Cheng, C. Y. (2009). Connexin 43 and plakophilin-2 as a protein complex that regulates blood-testis barrier dynamics. Proc. Natl. Acad. Sci. U.S.A. 106, 10213-10218. doi: 10.1073/pnas.0901700106

Li, X., Lynn, B. D., and Nagy, J. I. (2012). The effector and scaffolding proteins AF6 and MUPP1 interact with connexin36 and localize at gap junctions that form electrical synapses in rodent brain. Eur. J. Neurosci. 35, 166-181. doi: 10.1111/j.1460-9568.2011.07947.x

Lichtenstein, A., Minogue, P. J., Beyer, E. C., and Berthoud, V. M. (2011). Autophagy: a pathway that contributes to connexin degradation. J. Cell Sci. 124, 910-920. doi: 10.1242/jcs.073072

Liu, J., Ek Vitorin, J. F., Weintraub, S. T., Gu, S., Shi, Q., Burt, J. M., et al. (2011a). Phosphorylation of connexin 50 by protein kinase A enhances gap junction and hemichannel function. J. Biol. Chem. 286, 16914-16928. doi: 10.1074/jbc.M111.218735

Liu, J., Xu, J., Gu, S., Nicholson, B. J., and Jiang, J. X. (2011b). Aquaporin 0 enhances gap junction coupling via its cell adhesion function and interaction with connexin 50. J. Cell Sci. 124, 198-206. doi: 10.1242/jcs.072652

Liu, L., Li, Y., Lin, J., Liang, Q., Sheng, X., Wu, J., et al. (2010). Connexin43 interacts with Caveolin-3 in the heart. Mol. Biol. Rep. 37, 1685-1691. doi: 10.1007/s11033-009-9584-5

Liu, Q., Chen, X., Macdonnell, S. M., Kranias, E. G., Lorenz, J. N., Leitges, M., et al. (2009). Protein kinase C\{alpha\}, but not PKC\{beta\} or PKC\{gamma\}, regulates contractility and heart failure susceptibility: implications for ruboxistaurin as a novel therapeutic approach. Circ. Res. 105, 194-200. doi: 10.1161/CIRCRESAHA.109.195313

Lo, C. W. (2000). Role of gap junctions in cardiac conduction and development: insights from the connexin knockout mice. Circ. Res. 87, 346-348. doi: 10.1161/01.RES.87.5.346

Ludwig, M.-G., and Seuwen, K. (2002). Characterization of the human adenylyl cyclase gene family: cDNA, gene structure, and tissue distribution of the nine isoforms. J. Recept. Signal Transduct. Res. 22, 79-110. doi: 10.1081/RRS120014589

Maeda, S., Nakagawa, S., Suga, M., Yamashita, E., Oshima, A., Fujiyoshi, Y., et al. (2009). Structure of the connexin 26 gap junction channel at 3.5 A resolution. Nature 458, 597-602. doi: 10.1038/nature07869

Majoul, I., Shirao, T., Sekino, Y., and Duden, R. (2007). Many faces of drebrin: from building dendritic spines and stabilizing gap junctions to shaping neuritelike cell processes. Histochem. Cell Biol. 127, 355-361. doi: 10.1007/s00418-0070273-y

Mangat, R., Singal, T., Dhalla, N. S., and Tappia, P. S. (2006). Inhibition of phospholipase C-gamma 1 augments the decrease in cardiomyocyte viability by H2O2. Am. J. Physiol. Heart Circ. Physiol. 291, H854-H860. doi: 10.1152/ajpheart.01205.2005

Márquez-Rosado, L., Singh, D., Rincón-Arano, H., Solan, J. L., and Lampe, P. D. (2012). CASK (LIN2) interacts with Cx43 in wounded skin and their coexpression affects cell migration. J. Cell Sci. 125, 695-702. doi: 10.1242/jcs.084400 
Marx, S. O., Reiken, S., Hisamatsu, Y., Jayaraman, T., Burkhoff, D., Rosemblit, N., et al. (2000). PKA phosphorylation dissociates FKBP12.6 from the calcium release channel (ryanodine receptor): defective regulation in failing hearts. Cell 101, 365-376. doi: 10.1016/S0092-8674(00)80847-8

Meij, J. T., Panagia, V., Mesaeli, N., Peachell, J. L., Afzal, N., and Dhalla, N. S. (1997). Identification of changes in cardiac phospholipase $\mathrm{C}$ activity in congestive heart failure. J. Mol. Cell. Cardiol. 29, 237-246. doi: 10.1006/jmcc.1996.0268

Meyer, J., Mai, M., Ortega, G., Mössner, R., and Lesch, K.-P. (2002). Mutational analysis of the connexin 36 gene (CX36) and exclusion of the coding sequence as a candidate region for catatonic schizophrenia in a large pedigree. Schizophr. Res. 58, 87-91. doi: 10.1016/S0920-9964(02)00206-2

Meyer, R. A., Laird, D. W., Revel, J. P., and Johnson, R. G. (1992). Inhibition of gap junction and adherens junction assembly by connexin and A-CAM antibodies. J. Cell Biol. 119, 179-189. doi: 10.1083/jcb.119.1.179

Mitrovic, V., Jovanovic, A., and Lehinant, S. (2011). Soluble guanylate cyclase modulators in heart failure. Curr. Heart Fail. Rep. 8, 38-44. doi: 10.1007/s11897010-0045-1

Moehle, M. S., Luduena, R. F., Haroutunian, V., Meador-Woodruff, J. H., and McCullumsmith, R. E. (2012). Regional differences in expression of $\beta$-tubulin isoforms in schizophrenia. Schizophr. Res. 135, 181-186. doi: 10.1016/j.schres.2011.12.010

Neumann, J., Schmitz, W., Scholz, H., von Meyerinck, L., Döring, V., and Kalmar, P. (1988). Increase in myocardial Gi-proteins in heart failure. Lancet 2, 936-937. doi: 10.1016/S0140-6736(88)92601-3

Niger, C., Hebert, C., and Stains, J. P. (2010). Interaction of connexin43 and protein kinase C-delta during FGF2 signaling. BMC Biochem. 11:14. doi: 10.1186/14712091-11-14

Nishii, K., Kumai, M., and Shibata, Y. (2001). Regulation of the epithelialmesenchymal transformation through gap junction channels in heart development. Trends Cardiovasc. Med. 11, 213-218. doi: 10.1016/S10501738(01)00103-7

Olearczyk, J. J., Stephenson, A. H., Lonigro, A. J., and Sprague, R. S. (2004). Heterotrimeric $\mathrm{G}$ protein $\mathrm{Gi}$ is involved in a signal transduction pathway for ATP release from erythrocytes. Am. J. Physiol. Heart Circ. Physiol. 286, H940-H945. doi: 10.1152/ajpheart.00677.2003

Olk, S., Turchinovich, A., Grzendowski, M., Stühler, K., Meyer, H. E., Zoidl, G., et al. (2010). Proteomic analysis of astroglial connexin43 silencing uncovers a cytoskeletal platform involved in process formation and migration. Glia 58, 494-505. doi: 10.1002/glia.20942

Orellana, J. A., Hernández, D. E., Ezan, P., Velarde, V., Bennett, M. V. L., Giaume, C., et al. (2010). Hypoxia in high glucose followed by reoxygenation in normal glucose reduces the viability of cortical astrocytes through increased permeability of connexin 43 hemichannels. Glia 58, 329-343. doi: 10.1002/glia.20926

Otaegui, D., Querejeta, R., Arrieta, A., Lazkano, A., Bidaurrazaga, A., Arriandiaga, J. R., et al. (2010). Phospholipase Cbeta4 isozyme is expressed in human, rat, and murine heart left ventricles and in HL-1 cardiomyocytes. Mol. Cell. Biochem. 337, 167-173. doi: 10.1007/s11010-009-0296-x

Ouyang, X., Winbow, V. M., Patel, L. S., Burr, G. S., Mitchell, C. K., and O’Brien, J. (2005). Protein kinase A mediates regulation of gap junctions containing connexin 35 through a complex pathway. Brain Res. Mol. Brain Res. 135, 1-11. doi: 10.1016/j.molbrainres.2004.10.045

Palaniyandi, S. S., Sun, L., Ferreira, J. C. B., and Mochly-Rosen, D. (2009). Protein kinase C in heart failure: a therapeutic target? Cardiovasc. Res. 82, 229-239. doi: $10.1093 / \mathrm{cvr} / \mathrm{cvp} 001$

Patel, L. S., Mitchell, C. K., Dubinsky, W. P., and O’Brien, J. (2006). Regulation of gap junction coupling through the neuronal connexin $\mathrm{Cx} 35$ by nitric oxide and cGMP. Cell Commun. Adhes. 13, 41-54. doi: 10.1080/154190606 00631474

Patel, Y. M., Patel, K., Rahman, S., Smith, M. P., Spooner, G., Sumathipala, R., et al. (2003). Evidence for a role for Galphail in mediating weak agonist-induced platelet aggregation in human platelets: reduced Galphail expression and defective Gi signaling in the platelets of a patient with a chronic bleeding disorder. Blood 101, 4828-4835. doi: 10.1182/blood-2002-10-3080

Peracchia, C., Sotkis, A., Wang, X. G., Peracchia, L. L., and Persechini, A. (2000). Calmodulin directly gates gap junction channels. J. Biol. Chem. 275, 26220-26224. doi: 10.1074/jbc.M004007200

Potenza, N., Vecchione, C., Notte, A., De Rienzo, A., Rosica, A., Bauer, L., et al. (2005). Replacement of K-Ras with H-Ras supports normal embryonic development despite inducing cardiovascular pathology in adult mice. EMBO Rep. 6, 432-437. doi: 10.1038/sj.embor.7400397
Reich, M., Liefeld, T., Gould, J., Lerner, J., Tamayo, P., and Mesirov, J. P. (2006). GenePattern 2.0. Nat. Genet. 38, 500-501. doi: 10.1038/ng0506-500

Rhett, J. M., Jourdan, J., and Gourdie, R. G. (2011). Connexin 43 connexon to gap junction transition is regulated by zonula occludens-1. Mol. Biol. Cell 22, 1516-1528. doi: 10.1091/mbc.E10-06-0548

Rodríguez-Sinovas, A., Sánchez, J. A., Fernandez-Sanz, C., Ruiz-Meana, M., and Garcia-Dorado, D. (2012). Connexin and pannexin as modulators of myocardial injury. Biochim. Biophys. Acta 1818, 1962-1970. doi: 10.1016/j.bbamem.2011.07.041

Rohr, S. (2004). Role of gap junctions in the propagation of the cardiac action potential. Cardiovasc. Res. 62, 309-322. doi: 10.1016/j.cardiores.2003.11.035

Rose, B. A., Force, T., and Wang, Y. (2010). Mitogen-activated protein kinase signaling in the heart: angels versus demons in a heart-breaking tale. Physiol. Rev. 90, 1507-1546. doi: 10.1152/physrev.00054.2009

Rutkovskiy, A., Valen, G., and Vaage, J. (2013). Cardiac aquaporins. Basic Res. Cardiol. 108, 393. doi: 10.1007/s00395-013-0393-6

Rutledge, C., Ng, F., Sulkin, M., Greener, I., Arasu, D., Gemel, J., et al. (2012). c-Src regulation of Connexin43 remodeling in ischemic heart disease. Heart Rhythm 9, 1910. doi: 10.1016/j.hrthm.2012.09.093

Saeed, A. I., Sharov, V., White, J., Li, J., Liang, W., Bhagabati, N., et al. (2003). TM4: a free, open-source system for microarray data management and analysis. Biotechniques 34, 374-378.

Samoilova, M., Wentlandt, K., Adamchik, Y., Velumian, A. A., and Carlen, P. L. (2008). Connexin 43 mimetic peptides inhibit spontaneous epileptiform activity in organotypic hippocampal slice cultures. Exp. Neurol. 210, 762-775. doi: 10.1016/j.expneurol.2008.01.005

Sato, M., Jiao, Q., Honda, T., Kurotani, R., Toyota, E., Okumura, S., et al. (2009). Activator of $\mathrm{G}$ protein signaling 8 (AGS8) is required for hypoxia-induced apoptosis of cardiomyocytes: role of $\mathrm{G}$ betagamma and connexin 43 (CX43). J. Biol. Chem. 284, 31431-31440. doi: 10.1074/jbc.M109.014068

Sato, P. Y., Coombs, W., Lin, X., Nekrasova, O., Green, K. J., Isom, L. L., et al. (2011). Interactions between ankyrin-G, Plakophilin-2, and Connexin43 at the cardiac intercalated disc. Circ. Res. 109, 193-201. doi: 10.1161/CIRCRESAHA.111.247023

Schatteman, G. C., Motley, S. T., Effmann, E. L., and Bowen-Pope, D. F. (1995). Platelet-derived growth factor receptor alpha subunit deleted Patch mouse exhibits severe cardiovascular dysmorphogenesis. Teratology 51, 351-366. doi: 10.1002/tera.1420510602

Scherer, S. S., and Kleopa, K. A. (2012). X-linked charcot-marie-tooth disease. J. Peripher. Nerv. Syst. 17(Suppl. 3), 9-13. doi: 10.1111/j.15298027.2012.00424.x

Schwertz, D. W., and Halverson, J. (1992). Changes in phosphoinositide-specific phospholipase $\mathrm{C}$ and phospholipase $\mathrm{A} 2$ activity in ischemic and reperfused rat heart. Basic Res. Cardiol. 87, 113-127. doi: 10.1007/BF00801959

Schworer, C. M., Rothblum, L. I., Thekkumkara, T. J., and Singer, H. A. (1993). Identification of novel isoforms of the delta subunit of $\mathrm{Ca} 2+/$ calmodulindependent protein kinase II. Differential expression in rat brain and aorta. $J$. Biol. Chem. 268, 14443-14449.

Severs, N. J. (2001). Gap junction remodeling and cardiac arrhythmogenesis: cause or coincidence? J. Cell. Mol. Med. 5, 355-366. doi: 10.1111/j.15824934.2001.tb00170.x

Severs, N. J., Bruce, A. F., Dupont, E., and Rothery, S. (2008). Remodelling of gap junctions and connexin expression in diseased myocardium. Cardiovasc. Res. 80, 9-19. doi: 10.1093/cvr/cvn133

Severs, N. J., Coppen, S. R., Dupont, E., Yeh, H.-I., Ko, Y.-S., and Matsushita, T. (2004). Gap junction alterations in human cardiac disease. Cardiovasc. Res. 62, 368-377. doi: 10.1016/j.cardiores.2003.12.007

Shen, W., Li, L., Song, B., Li, W., Zhou, Z., and Guo, R. (2013). Platelet-derived growth factor-BB increases expression of connexin 43 in an extracellularregulated protein kinase-dependent manner in bladder smooth muscle cells. Int. J. Urol. 20, 123-130. doi: 10.1111/j.1442-2042.2012.03192.x

Singh, D., Solan, J. L., Taffet, S. M., Javier, R., and Lampe, P. D. (2005). Connexin 43 interacts with zona occludens- 1 and -2 proteins in a cell cycle stage-specific manner. J. Biol. Chem. 280, 30416-30421. doi: 10.1074/jbc.M506799200

Smyth, J. W., Vogan, J. M., Buch, P. J., Zhang, S.-S., Fong, T. S., Hong, T.T., et al. (2012). Actin cytoskeleton rest stops regulate anterograde traffic of connexin 43 vesicles to the plasma membrane. Circ. Res. 110, 978-989. doi: 10.1161/CIRCRESAHA.111.257964

Söhl, G., Maxeiner, S., and Willecke, K. (2005). Expression and functions of neuronal gap junctions. Nat. Rev. Neurosci. 6, 191-200. doi: 10.1038/nrn1627 
Solan, J. L., and Lampe, P. D. (2005). Connexin phosphorylation as a regulatory event linked to gap junction channel assembly. Biochim. Biophys. Acta 1711, 154-163. doi: 10.1016/j.bbamem.2004.09.013

Spray, D. C., and Iacobas, D. A. (2007). Organizational principles of the connexinrelated brain transcriptome. J. Membr. Biol. 218, 39-47. doi: 10.1007/s00232007-9049-5

Su, V., Cochrane, K., and Lau, A. F. (2012). Degradation of connexins through the proteasomal, endolysosomal and phagolysosomal pathways. J. Membr. Biol. 245, 389-400. doi: 10.1007/s00232-012-9461-3

Sun, Y., Zhao, X., Yao, Y., Qi, X., Yuan, Y., and Hu, Y. (2012). Connexin 43 interacts with Bax to regulate apoptosis of pancreatic cancer through a gap junctionindependent pathway. Int. J. Oncol. 41, 941-948. doi: 10.3892/ijo.2012.1524

Takasago, T., Imagawa, T., Furukawa, K., Ogurusu, T., and Shigekawa, M. (1991). Regulation of the cardiac ryanodine receptor by protein kinase-dependent phosphorylation. J. Biochem. 109, 163-170.

Takefuji, M., Wirth, A., Lukasova, M., Takefuji, S., Boettger, T., Braun, T., et al. (2012). G13-mediated signaling pathway is required for pressure overloadinduced cardiac remodeling and heart failure. Circulation 126, 1972-1982. doi: 10.1161/CIRCULATIONAHA.112.109256

Talhouk, R. S., Zeinieh, M. P., Mikati, M. A., and El-Sabban, M. E. (2008). Gap junctional intercellular communication in hypoxia-ischemia-induced neuronal injury. Prog. Neurobiol. 84, 57-76. doi: 10.1016/j.pneurobio.2007.10.001

Thévenin, A. F., Kowal, T. J., Fong, J. T., Kells, R. M., Fisher, C. G., Falk, M. M., et al. (2013). Proteins and mechanisms regulating gap-junction assembly, internalization, and degradation. Physiology (Bethesda) 28, 93-116. doi: 10.1152/physiol.00038.2012

Toyofuku, T., Akamatsu, Y., Zhang, H., Kuzuya, T., Tada, M., Hori, M., et al. (2001). $\mathrm{c}$-Src regulates the interaction between connexin-43 and ZO-1 in cardiac myocytes. J. Biol. Chem. 276, 1780-1788. doi: 10.1074/jbc.M005826200

Toyofuku, T., Yabuki, M., Otsu, K., Kuzuya, T., Hori, M., Tada, M., et al. (1998). Direct association of the gap junction protein connexin-43 with ZO-1 in cardiac myocytes. J. Biol. Chem. 273, 12725-12731. doi: 10.1074/jbc.273.21.12725

Tribulová, N., Knezl, V., Okruhlicová, L., and Slezák, J. (2008). Myocardial gap junctions: targets for novel approaches in the prevention of life-threatening cardiac arrhythmias. Physiol. Res. 57(Suppl. 2), S1-S13.

Tseng, G. C., Ghosh, D., and Feingold, E. (2012). Comprehensive literature review and statistical considerations for microarray meta-analysis. Nucleic Acids Res. 40, 3785-3799. doi: 10.1093/nar/gkr1265

Urschel, S., Höher, T., Schubert, T., Alev, C., Söhl, G., Wörsdörfer, P., et al. (2006). Protein kinase A-mediated phosphorylation of connexin36 in mouse retina results in decreased gap junctional communication between AII amacrine cells. J. Biol. Chem. 281, 33163-33171. doi: 10.1074/jbc.M606396200

Van den Akker, N. M. S., Winkel, L. C. J., Nisancioglu, M. H., Maas, S., Wisse, L. J., Armulik, A., et al. (2008). PDGF-B signaling is important for murine cardiac development: its role in developing atrioventricular valves, coronaries, and cardiac innervation. Dev. Dyn. 237, 494-503. doi: 10.1002/dvdy.21436

Van Zeijl, L., Ponsioen, B., Giepmans, B. N. G., Ariaens, A., Postma, F. R., Várnai, P., et al. (2007). Regulation of connexin43 gap junctional communication by phosphatidylinositol 4,5-bisphosphate. J. Cell Biol. 177, 881-891. doi: 10.1083/jcb.200610144

Verheule, S., and Kaese, S. (2013). Connexin diversity in the heart: insights from transgenic mouse models. Front. Pharmacol. 4:81. doi: 10.3389/fphar.2013.00081

Vessey, D. A., Li, L., and Kelley, M. (2010). Pannexin-I/P2X 7 purinergic receptor channels mediate the release of cardioprotectants induced by ischemic pre- and postconditioning. J. Cardiovasc. Pharmacol. Ther. 15, 190-195. doi: $10.1177 / 1074248409360356$

Vessey, D. A., Li, L., and Kelley, M. (2011). Ischemic preconditioning requires opening of pannexin-1/P2X(7) channels not only during preconditioning but again after index ischemia at full reperfusion. Mol. Cell. Biochem. 351, 77-84. doi: 10.1007/s11010-011-0713-9

Vinken, M., Decrock, E., Leybaert, L., Bultynck, G., Himpens, B., Vanhaecke, T., et al. (2012). Non-channel functions of connexins in cell growth and cell death. Biochim. Biophys. Acta 1818, 2002-2008. doi: 10.1016/j.bbamem.2011.06.011

Wall, M. E., Otey, C., Qi, J., and Banes, A. J. (2007). Connexin 43 is localized with actin in tenocytes. Cell Motil. Cytoskeleton 64, 121-130. doi: 10.1002/cm.20170

Wang, X.-H., Streeter, M., Liu, Y.-P., and Zhao, H.-B. (2009). Identification and characterization of pannexin expression in the mammalian cochlea. J. Comp. Neurol. 512, 336-346. doi: 10.1002/cne.21898
Wettschureck, N., Rütten, H., Zywietz, A., Gehring, D., Wilkie, T. M., Chen, J., et al. (2001). Absence of pressure overload induced myocardial hypertrophy after conditional inactivation of Galphaq/Galphal1 in cardiomyocytes. Nat. Med. 7, 1236-1240. doi: 10.1038/nm1101-1236

Winter, C. R., and Baker, R. C. (1995). L-glutamate-induced changes in intracellular calcium oscillation frequency through non-classical glutamate receptor binding in cultured rat myocardial cells. Life Sci. 57, 1925-1934. doi: 10.1016/00243205(95)02179-M

Xia, J., Fjell, C. D., Mayer, M. L., Pena, O. M., Wishart, D. S., and Hancock, R. E. W. (2013). INMEX-a web-based tool for integrative meta-analysis of expression data. Nucleic Acids Res. 41, W63-W70. doi: 10.1093/nar/gkt338

$\mathrm{Xu}$, J., and Nicholson, B. J. (2013). The role of connexins in ear and skin physiology - functional insights from disease-associated mutations. Biochim. Biophys. Acta 1828, 167-178. doi: 10.1016/j.bbamem.2012.06.024

Xu, X., Li, W. E., Huang, G. Y., Meyer, R., Chen, T., Luo, Y., et al. (2001). Modulation of mouse neural crest cell motility by N-cadherin and connexin 43 gap junctions. J. Cell Biol. 154, 217-230. doi: 10.1083/jcb.200105047

Yin, X. (2000). Casein Kinase II Phosphorylates Lens Connexin 45.6 and is involved in its degradation. J. Biol. Chem. 275, 6850-6856. doi: 10.1074/jbc.275.10.6850

Yu, X. S., and Jiang, J. X. (2004). Interaction of major intrinsic protein (aquaporin-0) with fiber connexins in lens development. J. Cell Sci. 117, 871-880. doi: 10.1242/jcs.00945

Yu, X. S., Yin, X., Lafer, E. M., and Jiang, J. X. (2005). Developmental regulation of the direct interaction between the intracellular loop of connexin 45.6 and the $\mathrm{C}$ terminus of major intrinsic protein (aquaporin-0). J. Biol. Chem. 280, 22081-22090. doi: 10.1074/jbc.M414377200

Zacchigna, S., Oh, H., Wilsch-Bräuninger, M., Missol-Kolka, E., Jászai, J., Jansen, S., et al. (2009). Loss of the cholesterol-binding protein prominin-1/CD133 causes disk dysmorphogenesis and photoreceptor degeneration. J. Neurosci. 29 , 2297-2308. doi: 10.1523/JNEUROSCI.2034-08.2009

Zemljic-Harpf, A. E., Godoy, J., Platoshyn, O., Asfaw, E. K., Busija, A. R., Domenighetti, A. A., et al. (2014). Vinculin directly binds zonula occludens1 and is essential for stabilizing connexin 43 containing gap junctions in cardiac Myocytes. J. Cell Sci. doi: 10.1242/jcs.143743. [Epub ahead of print].

Zemljic-Harpf, A. E., Miller, J. C., Henderson, S. A., Wright, A. T., Manso, A. M., Elsherif, L., et al. (2007). Cardiac-myocyte-specific excision of the vinculin gene disrupts cellular junctions, causing sudden death or dilated cardiomyopathy. Mol. Cell. Biol. 27, 7522-7537. doi: 10.1128/MCB.00728-07

Zhang, F., Cheng, J., Lam, G., Jin, D. K., Vincent, L., Hackett, N. R., et al. (2005). Adenovirus vector E4 gene regulates connexin 40 and 43 expression in endothelial cells via PKA and PI3K signal pathways. Circ. Res. 96, 950-957. doi: 10.1161/01.RES.0000165867.95291.7b

Zou, J., Salarian, M., Chen, Y., Veenstra, R., Louis, C. F., and Yang, J. J. (2014). Gap junction regulation by calmodulin. FEBS Lett. doi: 10.1016/j.febslet.2014.01.003. [Epub ahead of print].

Zuberi, Z., Birnbaumer, L., and Tinker, A. (2008). The role of inhibitory heterotrimeric $G$ proteins in the control of in vivo heart rate dynamics. Am. J. Physiol. Regul. Integr. Comp. Physiol. 295, R1822-R1830. doi: 10.1152/ajpregu.90625.2008

Conflict of Interest Statement: The authors declare that the research was conducted in the absence of any commercial or financial relationships that could be construed as a potential conflict of interest.

Received: 28 November 2013; accepted: 10 February 2014; published online: 27 February 2014.

Citation: Kurtenbach S, Kurtenbach S and Zoidl G (2014) Gap junction modulation and its implications for heart function. Front. Physiol. 5:82. doi: 10.3389/fphys. 2014.00082

This article was submitted to Membrane Physiology and Membrane Biophysics, a section of the journal Frontiers in Physiology.

Copyright (c) 2014 Kurtenbach, Kurtenbach and Zoidl. This is an open-access article distributed under the terms of the Creative Commons Attribution License (CC BY). The use, distribution or reproduction in other forums is permitted, provided the original author(s) or licensor are credited and that the original publication in this journal is cited, in accordance with accepted academic practice. No use, distribution or reproduction is permitted which does not comply with these terms. 